\title{
Evgenij Zamjatin, We and Tatjana Tolstaja, Kys': A Century of Envisaging a Dystopian Future
}

\author{
Petra Hesse*
}

\begin{abstract}
After World War I, the new Soviet government propagated one principal option to replace nationalism and its emotional appeal: Socialist rationalism was to inform all aspects of individual and social life.

One of the first dystopian novels of the Soviet period, Evgenij Zamjatin's We (1920), takes this idea to the extreme, thus warning the young state against the consequences of exclusive rationalism. After the end of the Soviet Union, another negative utopia, Tatjana Tolstaja's Kys' (2000), deals with the return of emotional nationalism at the cost of rationality. Both novels use the genre of dystopia as laboratory: With a starting point in their respective present, they outline a possible future development of individual man and mankind. The latter's reduction to either reason or emotion results in the individual's social de-contextualization and a loss of cultural competence, and both turn out to be hotbeds of violent upheaval and devastating insanity.
\end{abstract}

Key words: culture / aesthetics, dystopia, nation, New Man, rationalism, Soviet Union

\footnotetext{
* Institut für Slawistik, Alpen-Adria-Universität Klagenfurt; petra.hesse@aau.at
} 


\section{Introduction: Two Dystopian Novels Framing the 'Short $20^{\text {th }}$ century'}

One of the contemporary answers to the rise of nationalism in the $19^{\text {th }}$ century was the growing internationalism resulting in the foundation of the International Workingmen's Association or First International in London (1864). Its follow up, the Second International (1889), fell apart with the national closing of ranks in the wake of World War I. Vladimir I. Lenin and the socialist expectation of an imminent world revolution played a decisive part in the foundation of the Third International (1919) after the war and the Russian October Revolution.

In these years, a Russian social democrat, naval engineer, and man of letters, Evgenij Ivanovich Zamjatin (1884-1937), wrote a dystopian novel, $W e(M y)^{1}$, which at the time and ever since has been read as a warning against Soviet totalitarianism. Written in 1920, it became world famous, but never saw publication in the Soviet Union. This literary opening of the 'short $20^{\text {th }}$ century' depicts the world as "OneState", governed exclusively by reason and realised by the cooperation of the whole of mankind: The irrational ambitions, competition, and antagonism of nations, social classes, and other representatives of interests do not exist anymore. An analysis of the structure of this singular and total state, of individual life under its rule, and, on a meta-level, of some of the novel's basic narrative devices will disclose the problematic implications of modernity's exclusive faith in reason.

When the curtain fell on the Bolshevist real-life experiment, another dystopian novel took Zamjatin's literary exploration one step further towards the present: In the year 2000, the Russian feminist and writer Tatjana Nikitichna Tolstaja $\left({ }^{*} 1951\right)$ published her novel $K y s^{\prime 2}$, which depicts a world still consisting of one state that has, however, overcome and detached itself from the modernist option of rationality. National topoi and xenophobic stereotypes return, and the protagonist's present has taken on features of a stone - or in the Russian context rather: a wooden - age. This literary closing of the 'short $20^{\text {th }}$ century' in a number of aspects corresponds to Zamjatin's opening dystopia, and another analysis of state structure, of individual life and, again on a meta-level, of the novel's basic narrative devices will show the sinister implications of the abandonment of rationality in a new type of nationalism.

\footnotetext{
1 Evgenij Zamjatin, My. Romany, povesti, rasskazy, skazki, Moskva: Sovremennik 1989 (all quotes from this edition)

2 Tatjana Tolstaja, Kys'. Roman, Moskva: Podkova / Inostranka 2001 (all quotes from this edition).
} 


\section{State Structure and Individual Life in Zamjatin's We}

At first sight, the guiding principle of Zamjatin's "OneState” seems to be transparency. Transparency is guaranteed by the use of glass for all sorts of building and construction: The residential houses as well as the streets and all public institutions are made of glass, and even the high wall surrounding the known world consists of light green glass occasionally allowing the perception of a brown-eyed glance from the outside. People live in one glass room each, and the exact identification of all and everyone is enhanced by the combination of a letter and a number each individual bears, instead of a name. These signs of identity, engraved on a metal plate, are worn on his or her "unifa" - a word which according to the explanation the narrator gives in a footnote stems from the ancient term "uniform". People themselves are referred to as "numbers" and have to act in equal step, synchronised in a Taylorist manner by a central mechanism for time measuring. Even for their healthy strolls they go in geometrical formation, led by a marching band, and the so-called "sexual hours" each number has a right to twice a week have to be registered. On this condition, the number may finally lower a blend in his or her room for one hour - a last residue of privacy. There are no "private children" and, subsequently, no families. Procreation is regulated by a "maternity norm" of height and health. The absence of private property can be seen in close relation to this ban on $\mathrm{fa}$ miliar structures. Thus, the OneState offers technical answers to all emotional and social challenges.

The story of $W e$ is told by a first-person narrator, D-503. He is a leading mathematician and the constructor-in-chief of a huge spacecraft, the "Integral", designed to take human numbers into space and thereby to "integrate" possible other worlds out there into the earthly OneState - colonialism expands to the cosmos with the target of a "mathematically flawless happiness" (204). With regard to this mission, all human numbers are called upon to prepare poetic or other messages to the unknown extraterrestrials, and D-503 does so, taking notes about his everyday life and the progress of his work. These records show him to be a mathematician not only by profession, but with every fibre of his physical and mental existence. Thus, he characterises a strange female number he met not by her official identity, I-330, but by X. At first, this use of the representation of an unknown element in a mathematical equation is motivated by her steeply rising eyebrows and two deep wrinkles running down from her nose to the mouth. But later, with fascination growing into love and even addiction, D-503 still refuses to think of his feelings as something irrational - he insists on understanding by calculating this $\mathrm{X}$ in his mathematical world view.

When $\mathrm{X}=\mathrm{I}-330$ with a number of followers starts a revolt against the OneState and tries to enter and get hold of the spacecraft "Integral", its constructor-in-chief is torn 
between the two parties. His records show him trying hard to make up his mind: In one moment, he wants to decide for reason, in the next, he decides for love; he does not have any experience or knowledge supporting his individual efforts at solving his inner dilemma. This individual disruption mirrors the position of the OneState: For rationally legitimised power, an integration of reason and emotion is excluded by the same logic that constitutes the individual mathematician's consciousness.

Such exclusive rationality prefigures an observation the Russian philosopher Maja Soboleva made with regard to social philosophy of the early Soviet period: According to theorists like Bogdanov or Trotsky, the proletariat works in modern industrial plants and is, therefore, technically minded; thus, it "spontaneously extends the norms of rationality to all spheres of social life, including politics" (Soboleva 2017, 6). Soboleva continues to analyse this early socialist line of thought:

There was no need for ethics here, since the moral transformation of humanity was expected to result from the ontological transformation of society and from the correlating transformation of the mental structures of humanity. In other words, the new conditions of life would provide a solid ontological foundation for the formation of a new human being with a new morality. (ibid)

The new morality, however, did not grow 'automatically' out of the new social structure. Without it, Zamjatin's individual faces the demands of the - supposedly - rational OneState uncritically and is, at the same time, driven into active opposition by his or her emotion. To the very end of the novel, there is no solution, neither to the external conflict nor to the psychological dilemma: The outcome of the revolt remains open. But D-503, like many other numbers, is submitted to a surgical 'healing' of his brain: A small part, identified as the seat of "imagination" ("fantazija") is removed, and the numbers function again "like tractors looking human" (319).

\section{The Narrative Structure Underlying Zamjatin's Sujet}

At first sight thoroughly modernist, the text reveals its mythical dualist structure upon closer analysis: There is the confrontation of an inner and an outer world corresponding to the principles of reason and emotion. The inner world of the OneState has its technical neologisms and terminology, whereas the world outside the wall introduces a biblical name of evil in its propaganda graffiti: "Mefi", derived from Mephistopheles, the advocate of the human free will and choice. Thus, the Mefi people's revolt against 
the OneState is not only a random choice of irrationality, it follows the pattern of a mythical war between good and evil.

The Russian folklorist Vladimir Jakovlevich Propp (1928) found this pattern in Russian fairy tales and it pertains to works of fantasy up to our day. In folklore as well as in the modern novel, a fault in the world of good serves as a starting point for the hero's quest, which leads him to transgress the borders of his world. The fault in Zamjatin's OneState can be described in terms of reason: The "beneficent" role of its leader, the anonymous "Benefactor", is more and more exposed to mistrust by various appearances of secret police agents, by spies controlling private notes and correspondence, by the capture and execution of critical numbers. The state's guiding principle, transparency, discloses its nature as a one-way demand of the powerful to their subjects. But all their power and measures of control cannot completely modernise human consciousness: Even the mathematician D-503 on various occasions longs for a mythical harmony between his inner and the outer world, his calculating mind and a clear blue sky without amorphous, i.e. incalculable clouds. He irrationally longs to belong to a world of clear and transparent, rational regulations - a world which does not exist in separation from the irrational, neither in the outside world nor in his own mind. Man's mind only in part corresponds to the rational inside of the modern state, whereas another part of his own inside world corresponds to the state's outside. An unsolvable dilemma, an X?

\section{State Structure and Individual Life in Tolstaja's Kys'}

The early Soviet rupture between reason and emotion is not healed by the end of the century, on the contrary: After another war and a final "big bang", discredited reason is finally defeated and vanished altogether from social life in a state that in the course of its history had many names, but in the end of a long enumeration of patron politicians is called "Moscow". As in Zamjatin's text, the capital now is a megalopolis comprising the whole of the known world. But it is protected by an interior, mental wall: by fear of the unknown dangers lurking in the North, South, and West. Moscow "on the seven hills" (3) evokes the medieval orthodox doctrine of "Moscow, the third Rome" and legitimises the claim to hegemony; it results in widespread antagonism towards all and everyone that are not "ours".

All the Moscow buildings are wooden huts, the political elite live in wooden palaces, the objects of daily use are carved of wood - the traditional stereotype of wooden Russia determines every detail of life in the agglomeration. Metallurgy is forgotten. Agriculture in an eternal winter serves one's own requirements only, and the poor feed on mice 
that have become a sort of currency like the marten in the Middle ages. There is no religion or creed, no generally valid law and no morality; everybody seems to take force, theft, and animistic superstition for granted. In this context, the novel's title Kys' denotes a monster of the wilderness that is feared to tear aberrant inhabitants to pieces; in the Chechen language, "kys" means winter - an association which is closely related to the Russian imperial claim to Chechnya. Quite in tone, the human offspring of the survivors of the big bang call each other "little rowdies" ("golubchiki") instead of 'people', but there are other groups of beings with genetic mutations as well.

Political power manifests itself in one single prohibition which, however, is at the root of society's mental depravity: the total ban on the books of old. Old books are said to cause illness, just like mushrooms which after the unspecified wartime explosion became toxic - a hint at a nuclear catastrophe? At any rate, it is up to the state to decree what is ill and what is healthy. None of the rowdies has a rational insight into the nature of these dangers, but they fear the "red sledges" of the ruler's secret police. ${ }^{3}$ Reading and writing, however, are principally allowed, and Benedict, the novel's protagonist, even works as a scribe in a state department, copying harmless children's verses about birds and flowers. These texts, as well as many others, are proclaimed to have sprung from the actual ruler's genius: He claims to have written "a schopenhauer" and, moreover, verses by Goethe as well as by Mandel'shtam (25-26) - obviously, there are no unpolitical criteria for a contextualisation of utterings such as authorship, genre and voice, aesthetics, subject matter, or historical context. Any textual information is taken at surface value, and "a pushkin" is believed to be an object, almost a fetish, promising happiness and a sense in life. Emotional longing is projected on to physical symptoms, and the incomprehensible "felosofy" ("felosofija") of old gives pseudo-explanations.

When Benedict marries the daughter of the state's new ruler, whom he assisted in overthrowing the old, Lilliput one, he gets access to a huge depository of forbidden books all of which he devours in the course of several years. But he cannot digest all this information and is aware of lacking some sort of clue to it. His only way of getting some sense out of it is physical: He takes the books and orders them alphabetically. In the end he is haunted by a poem by Aleksandr Pushkin whose metaphor of "gnawing mice" he cannot but take literally - but there are no mice in the house, in which every-

3 The basic idea of the sujet resembles that of Fabrenheit 451, "a 1966 British dystopian drama film directed by François Truffaut and starring Oskar Werner, Julie Christie, and Cyril Cusack. Based on the 1953 novel of the same name by Ray Bradbury, the film takes place in a controlled society in an oppressive future in which the government sends out firemen to destroy all literature to prevent revolution and thinking. This was Truffaut's first colour film as well as his only English-language film. At the 1966 Venice Film Festival, Fabrenheit 451 was nominated for the Golden Lion“ (Wikipedia). 
thing edible has long been consumed. In search of meaning he goes mad, aberrant and driven by the Kys' of common superstition.

\section{The Narrative Structure Underlying Tolstaja's Sujet}

Tolstaja's rowdies are caught in iteration: In principal, they have all the information of the past and present at hand, but they are unable to understand and make appropriate use of it for lack of context. Thus, they are confronted with a mixture of national stereotypes, of literature classical and modern, belletrist and documentary, of aesthetic and practical texts, but they are denied any criterion for differentiation. The text of the novel depicts this state of mind by mixing archaisms and neologisms, terminology and slang, rumour and historical knowledge, and by repeating quotes from Russian and world literature over many pages. In effect, the whole history of culture, Russian and Western, is there, but access to and understanding of the treasures are lost. The individual confronts a mass of information, but he or she is denied the means to cope with it.

\section{Conclusion}

A comparison of the two dystopian novels shows that in the beginning and in the end of the 'short $20^{\text {th }}$ century', the $19^{\text {th }}$ century idea of the national state is obsolete. Its successors - at least in the laboratory of the novel - are oppressive systems in which the individual faces political power in isolation, without the support of any sort of social context: None of the modernist or the postmodern ideas of what a human being is allows him or her to lead a fulfilling life in the context of human relationships and of society. A number lacks almost all emotional ties to his fellow numbers, whereas a rowdy acts without the learning and the rational discipline social and intellectual life require, among individuals as well as among political groups or nations.

Both types of reduction result in de-contextualisation: Absolute rationality not only answers the demands of analysis and conclusion, it claims a validity which is principally boundless and aims at overcoming emotion. Mere irrationality neither knows nor acknowledges limits to its drives and desires. Both follow a tendency of their own: the tendency towards expansion and, in the long run, self-destruction. 


\section{References}

Propp, Vladimir Ja. 1928. The Morphology of the Fairy Tale [Морфология сказки]. Leningrad. Soboleva, Maja. 2017. “The Concept of the 'New Soviet man' and Its Short History.” CanadianAmerican Slavic Studies 51: 1-22.

Tolstaja, Tatjana. 2001. Kys'. Roman, Moskva: Podkova/Inostranka.

Zamjatin, Evgenij.1989. My. Romany, povesti, rasskazy, skazki. Moskva: Sovremennik. 